\title{
Petrology, Geochemistry and Geodynamic Significance of the Mafic and Ultramafic Rocks of the Akou (Okondja Basin, Gabon)
}

\author{
Cedric Ligna, \\ Mathieu Moussavou, \\ Karen Bakakas, \\ Michel Mbina,
}

Université des Sciences et Techniques de Masuku, URESTE, Département de Géologie, Franceville, Gabon

Tomohiko Sato,

Tokyo Institute of Technology, Earth-Life Science Institute, Tokyo, Japan

Doi: 10.19044/esj.2018.v14n12p347 URL:http://dx.doi.org/10.19044/esj.2018.v14n12p347

\begin{abstract}
The Akou section (Okondja in the Francevillian Basins, Gabon) has a set of mafic and ultrmafic magmatic rocks with various deposit patterns; interbedded basaltic flows, sills and small intrusive bodies within the formations FB francevillian series. The succession of these rocks pyroxenites, gabbros and basalts characterizes the oceanic crust. These rocks mainly consists of olivine, pyroxene, amphibole and biotite. This mineralogical continuation shows that these rocks result from process of split crystallization of an ultramafic magma. The geochemical analyses reveal the major elemental composition such as $\mathrm{Na}_{2} \mathrm{O}(0.24-3.47)$ and $\mathrm{K}_{2} \mathrm{O}$ (0.04-3.95). These values indicate that these series are originated from the alkaline magma, which is associated with within plate oceanic volcanicity.
\end{abstract}

Keywords: Okondja basin, Akou, alkaline, oceanic crust, within plate

\section{Introduction}

The Okondja basin is one of the four Francevillian intracratonic basins (Weber et al., 2016; Feybesse et al., 1999), filled with the Paleoproterozoic Francevillian Formation $(2.2 \mathrm{Ga})$. Recent findings in these fields indicate the presence of multicellular macrofossils in the Franceville basin (El Albani et al., 2010) and in Okondja basin (Moussavou et al., 2015; Edou-Minko et al., 2016; Edou-Minko et al., 2017). The Francevillian basin including the emplacement coincided with the period of great oxygenation of the Earth 
(GOE) is known for these natural fission reactors of Oklo (Gauthier-Lafaye, 1986) and for these organic matters abundant. They present the very low values $\left(\delta^{13} \mathrm{C}-46 \%\right.$ in the Franceville basin) that Weber, 2013 associate with activity of methanotrophic microorganisms. This basin is characterized by significant magmatic activities during sedimentation. Various magmatic rocks are distributed in the Okondja basin, particularly in the Ngoutou complex to the North, while mafic and ultramafic rocks outcrop near Ambinda to the East. This study is devoted to the magmatic rocks observed in small solid intrusive masses or interstratified in various formations of the FB unit along the Akou River. The FB unit is primarily basaltic pyroxenites, gabbros, and basalts. In this section, Moussavou et al., 2015; Edou-Minko et al., 2016; Edou-Minko et al., 2017 studied the fossils, Thiéblemont et al., 2009 studied the petrography, the nature and the geochronologic of these rocks. These previous projects were all conducted by mining companies, and certain information remained confidential to date. In spite of this work, many uncertainties remain concerning the petrography and geochemistry and, especially, the geodynamic history of these rocks. The aim of this work is to define the possible chemical relations between these rocks and to discuss the geodynamic context of their emplacement.

\section{Geological setting}

In the Francevillian basins, unmetamorphosed volcanogenic detrital formations with a total thickness of 1000 to $4000 \mathrm{~m}$ were deposited approximately $2214 \pm 24 \mathrm{Ma}$ (Sawaki et al., 2016). The Francevillian basins are subdivided into four sub-basins: Lastourville, Booué, Franceville, and Okondja. The basins are surrounded by the metamorphic and plutonic North Gabon Massif to the north, the solid mass of the Chaillu Massif to the south (Fig. 1A), the Mesozoic and Cenozoic terrestrial formations of the Congo Basin to the east (series of pools and flats), and the Ogooue Orogenic Belt to the west.

The stratigraphic column of the Francevillian Formation was subdivided by Weber (1968) into five units; FA, FB, FC, FD, and FE (Fig. 1B). FA, the basal unit of the Francevillian series, consists of fluvio-deltaic conglomerate and sandstone (Haubensack, 1981; Gauthier-Lafaye, 1986; Ossa Ossa, 2010) with a thickness reaching $1200 \mathrm{~m}$. FA in the Okondja basin, similar to FA of the Franceville basin, is described as mudstone, both by its petrographic characteristics and depositional environment.

FB is of marine origin (Azzibrouck, 1986; Pambo, 2004). In the Okondja basin, the sequence of this formation differs radically from other basins with alternation of the various facies and the addition of interstratified volcanogenic rocks. In the studied section, cherts in the FB units overlay sandstone, ampelite, pelite, volcanic rocks, sandstone tuffs and pyroclastic 
elements. Ampelites are highly fissile fine carbonaceous black mudstones millimeters to centimeters thick and are associated the fine sandstones. The sand pelites can be rich in detrital quartz and are gray or black rocks. In these facies, one notes the presence of eruptive rocks that form a unit that may crosscut the earlier formations or be interstratified.

FC consists of laterally extensive cherts from 5 to $50 \mathrm{~m}$ thick, corresponding to a single tectonic lull period with the local addition of stromatolites and sebkas with évaporites. Ash tuffs are visible in this formation, as homogeneous facies, brechic, fine ribbon beds or, occasionally, laminar flow. Pyrite is almost always visible and very abundant at certain depths. FD is a volcanogenic formation from which the transition with the FC is rather progressive and is marked by 50 to $200 \mathrm{~m}$ of black shales to pyroclastic material. FE consists of an alternation of shales and sandstones and is rich in volcanic tuffs and ash tuffs with meter-scale thickness.

The peridotites are generally associated with the gabbros and volcanic rocks. The mafic and ultramafic rocks of the Akou River are observed as sills, dykes and plutons (Weber, 1968, 1969). Pyroxenite and gabbro are also found with the basalt volcanic rocks (Pascal, 1962; Weber, 1969). The volcanic rocks alternate with sedimentary facies of Francevillian B. These rocks are evidence of volcanicity related to the distensif context in the Okondja basin (Weber, 1969; Thiéblemont, 2009).

The studied area is located at the eastern part of the Okondja basin in the Francevillian basins. We conducted fieldwork along the Akou River to determine the lithostratigraphy and collect rock samples. Samples were identified within the lithological succession, and their positions were noted within the basin. The stratigraphic column highlights (Fig. 2) the stratigraphic relationships between the sedimentary units of the Francevillian series, represented by FB and FC. The mafic and ultramafic units contain (Fig. 3) basaltic flows, sills, and small plutons, which overlap or are interbedded within the layers of the FB unit. The sills are concordant bodies with entablature jointing and are observed in a succession that includes basalts and silty sandstone layers rich in organic matter. Plutons are observed as small intrusions. The establishment of these magmatic rocks did not develop a contact metamorphism of sedimentary facies. The gabbros and pyroxenites do not have a fixed border. The absence of metamorphism in the study area is general throughout Francevilian basin. 


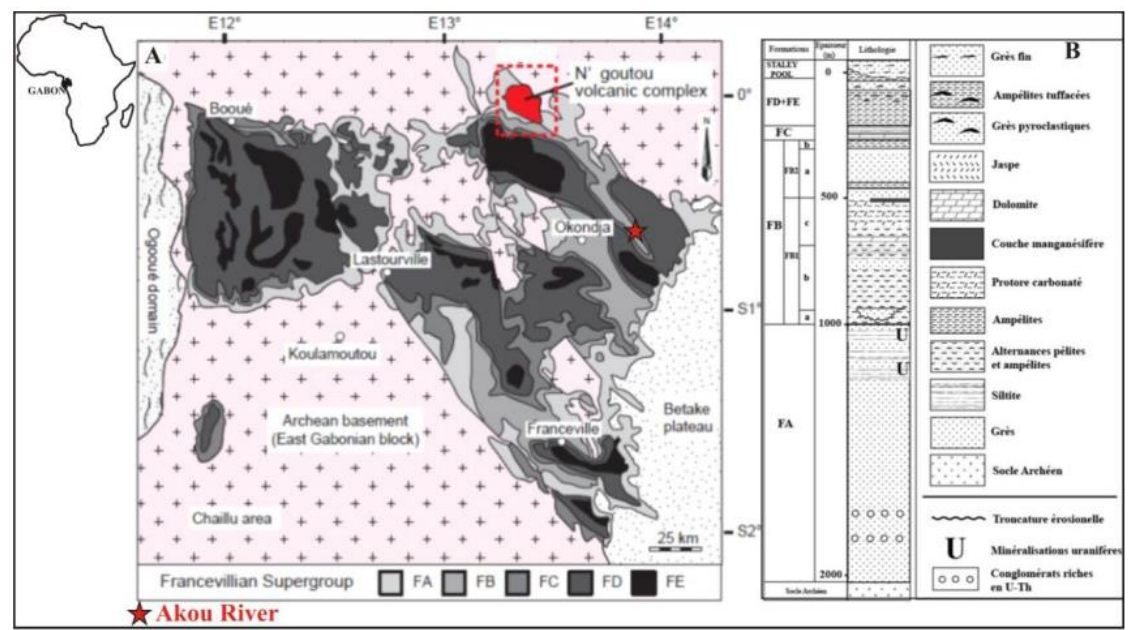

Figure 1: (A) Geological map of the Francevillian (modified from Sawaki et al., 2016); (B): Lithostratigraphic succession of the Francevillian basins (modified from Ossa Ossa, 2010).

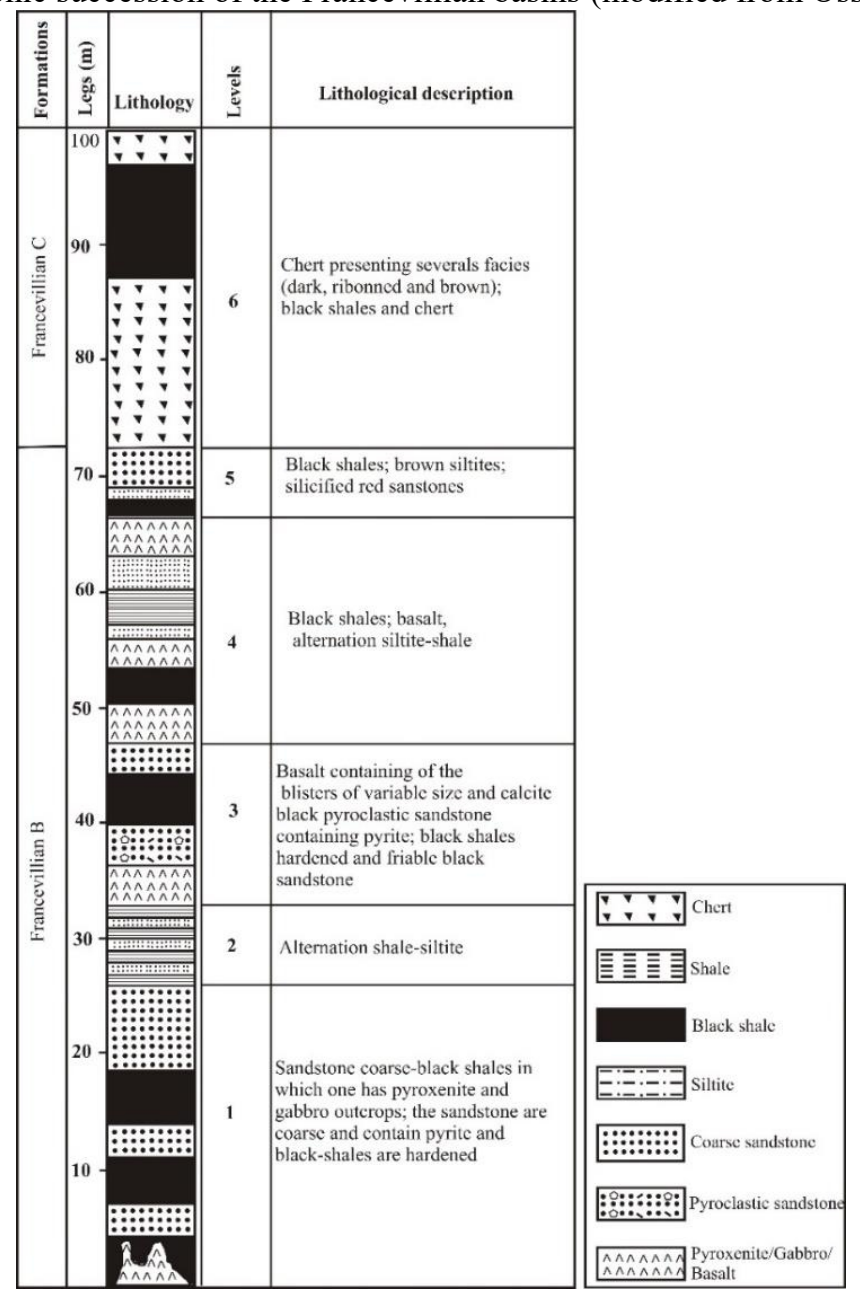

Figure 2: Lithostratigraphic succession of the Akou River, in the Okondja basin 


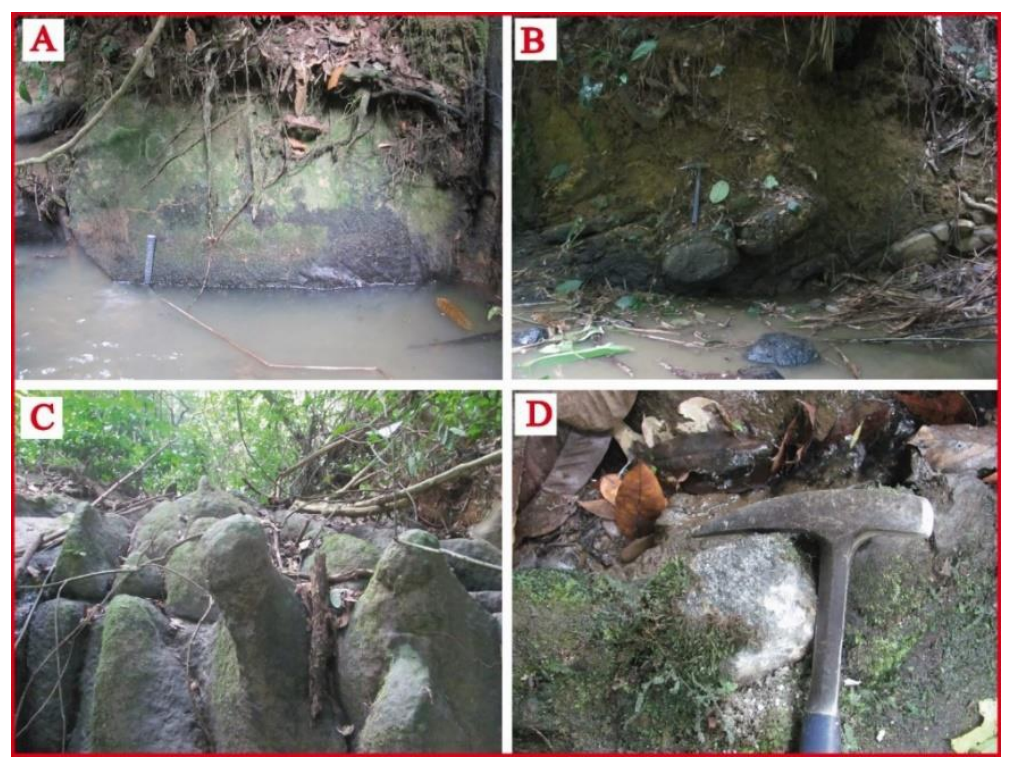

Figure 3: Outcrops of basic and ultrabasic rocks of Akou River.(A and B): Basalt, (C):

Pyroxenite, (D): Gabbro

\section{Methodology}

The rock samples were selected, that is basalt, gabbro and pyroxenite. These samples were made into thin sections for microscopic observation at the University of Science and Technology of Masuku. Optical microscopy of the thin sections enabled us to determine paragenesis and textures of the rocks. The observations were carried out in mode "not analyzed polarized light and in analyzed polarized light." An OPTIKA B-353 pol microscope was used, equipped with a Canon DS126271 camera for digitizing the observations with EOS Utility software. Major and trace elements were determined by X-ray fluorescence spectrometry (XRF) at the Geological Survey of Norway, using a PANalytical Axios $4 \mathrm{~kW}$ X-ray spectrometer equipped with a RhX-ray tube (incertitude \pm 0.01$)$. For major elements $0.6 \mathrm{~g}$ of pre-ignited $\left(1000^{\circ} \mathrm{C}\right)$ fineground sample material was mixed with $4.2 \mathrm{~g} \mathrm{Li} 2 \mathrm{~B} 4 \mathrm{O} 7$ and fused to a bead in a CLAISSE FLUXER-BIS. For trace element analysis $1.2 \mathrm{~g}( \pm 0.005 \mathrm{~g})$ of Hoechst wax and $9.6 \mathrm{~g}( \pm 0.005 \mathrm{~g})$ of sample were mixed in a Spex Mixer/Mill for at least 1 minute. The mixture was then pressed to a pellet in a Herzog pelletizing press (approx. $20 \mathrm{kN}$, time $=20$ seconds).

\section{Results \\ Petrography}

The basalts are melanocratic rocks with micritic textures, made up of plagioclase microlites, xenomorphic pyroxene (Fig. 4A4B). Not all of the rock is crystallized; part is glass. Matrix is approximately $60 \%$ plagioclase. The gabbros are holocrystalline mesocratic rocks with grainy texture, composed of 
pyroxene (augite), amphibole, plagioclase, biotite, apatite and other opaque minerals (Fig. 4C). Certain minerals are automorphic (amphibole, pyroxene and apatite) and others present polysynthetic macles (plagioclases). The amphiboles constitute nearly $30 \%$ of the rock. The pyroxenites are grainy green-dark rocks with olivine that has not undergone serpentinization, pyroxene, amphibole, biotite, plagioclase (white feldspar), and diopside (Fig. 4D). The additional minerals are apatite and chromite. The majority of minerals are automorphic to subautomorphe. Olivine represents approximately $40 \%$ of the rock. The minerals are generally xenomorphic with many cracks in the centers and opaque inclusions. From macroscopic and microscopic descriptions, this rock can be regarded as an olivine pyroxenite.
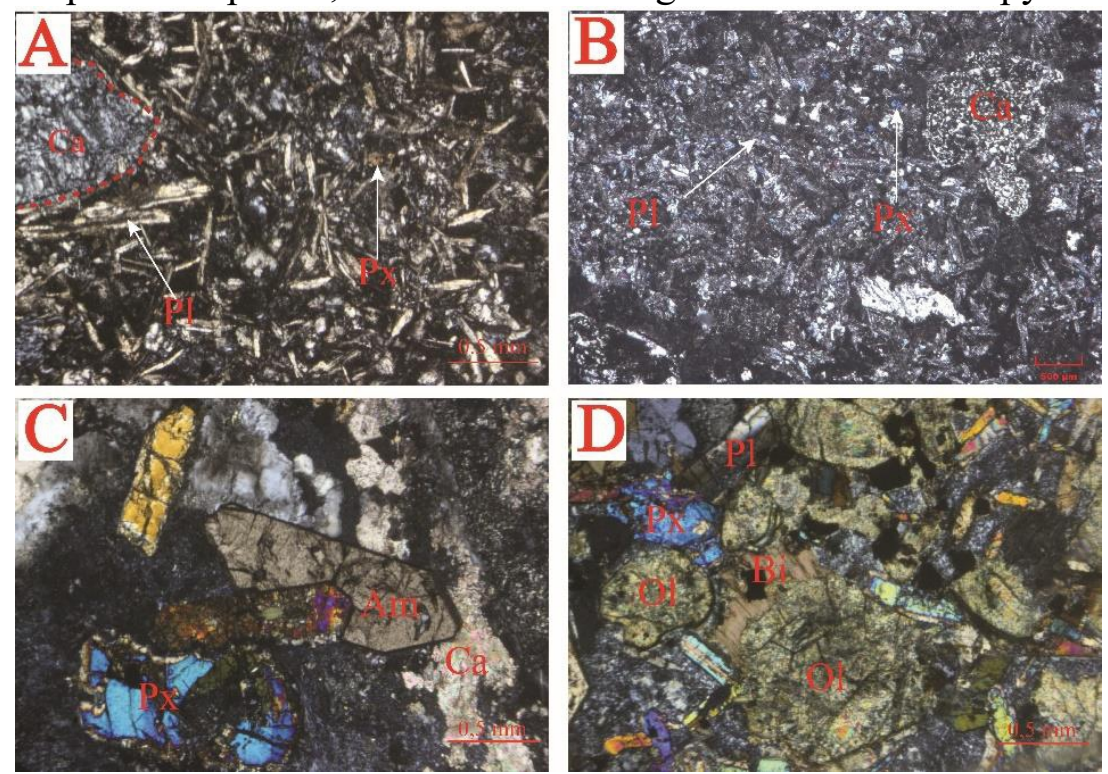

Figure.4: Thins sections of magmatic rocks of Akou River. A: Gabbro, B: Basalt, C: Pyroxenite; Ca: calcite, Ol: Olivine, Am: Amphibole, Bi: biotite, Pl: plagioclase, Mat: matrix, op: opaque

\section{Geochemistry}

The mafic and ultramafic rocks of the Akou River are volcanic rocks and plutonic. The mafic rocks (volcanic) are characterized by basalts whose content of $\mathrm{SiO} 2$ varies between 43.5 and $50 \%$. The ultramafic rocks (plutonic) are characterized by gabbros and pyroxenites whose content of $\mathrm{SiO} 2$ varies between 41.5 and $45.8 \%$. In the diagram TAS $\left(\mathrm{SiO}_{2} \mathrm{vs} \mathrm{Na}_{2} \mathrm{O}+\mathrm{K}_{2} \mathrm{O}\right)$ (Fig 5), the samples these rocks studied are projected in the field of the series alkaline and subalkaline and concentrate in the fields of basalt, trachy-basalt, tephrite basanite and picrobasalte (Le Bas et al., 1986; Le Maître et al., 1989) 


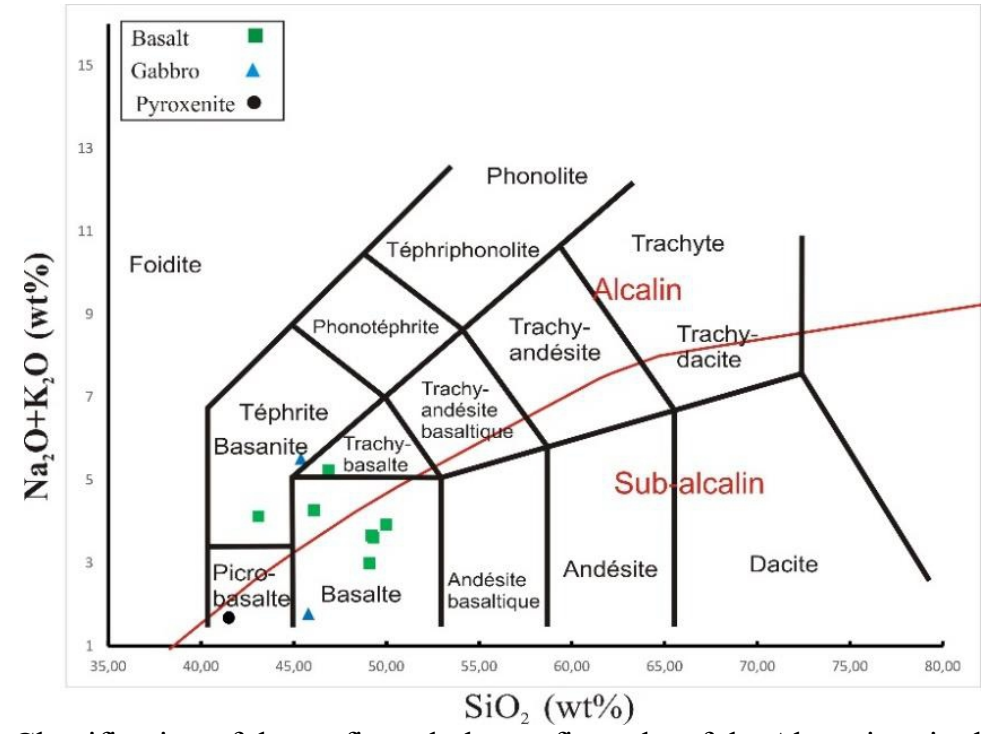

Figure 5:Classification of the mafic and ultramafic rocks of the Akou river in the diagram

TAS $\left(\mathrm{SiO}_{2} \mathrm{vs} \mathrm{Na}_{2} \mathrm{O}+\mathrm{K}_{2} \mathrm{O}\right)$ (Le Bas et al., 1986; Le Maître et al., 1989). The red line separates the field from the alkaline rocks of the field of the subalkaline rocks (Irvine and Baragar, 1971). Caption: black round: Pyroxenite, blue Triangle: Gabbro, green Square: basalt.

In the $\mathrm{Nb} / \mathrm{Y}-\mathrm{Zr} / \mathrm{TiO}_{2}$ diagram of Winchester and Floyd (1976) (Fig 6) which utilizes the motionless elements with the processes of the metamorphism and of deterioration $(\mathrm{Nb}, \mathrm{Y} \mathrm{Ti}$ and $\mathrm{Zr}$ ) these mafic and ultramafic rocks of the Akou River are placed primarily in the field of the alkaline series and place themselves in the fields of basalts and the basanites/néphéline. Two basalt samples are placed in the field of subalkaline series and correspond to basalts.

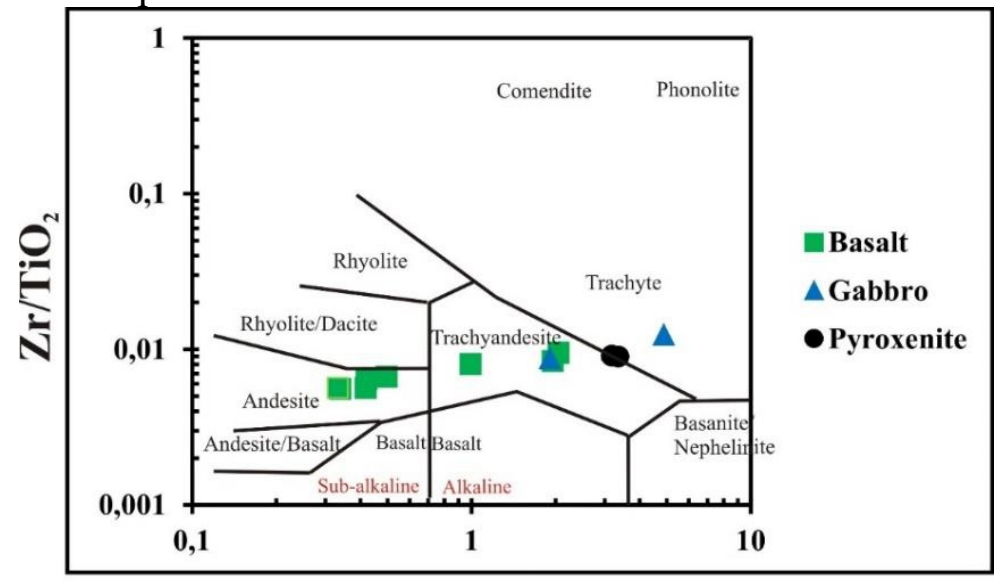

$\mathrm{Nb} / \mathrm{Y}$

Figure 6Classification of the mafic and ultramafic rocks of the Akou River in the $\mathrm{Nb} / \mathrm{Y}$ $\mathrm{Zr} / \mathrm{TiO}_{2}$ diagram of Winchester (1976). Caption: black round: Pyroxenite, blue Triangle:

Gabbro, green Square: basalt. 
In the diagram $\mathrm{TiO}_{2}-\mathrm{MnO}-\mathrm{P}_{2} \mathrm{O}_{5}$ (Mullen, 1983) these samples are placed in the fields of the OIA, the MORB and of the IAT. In the diagram Nb$\mathrm{Zr}$ there (Meschede, 1986) these samples are placed in the field of basalts within plate (WPB and WPA). The whole of the mafic and ultramafic rocks of the Akou river show characters of the within plate rocks with alkaline affinity in these diagrams geotectonic.
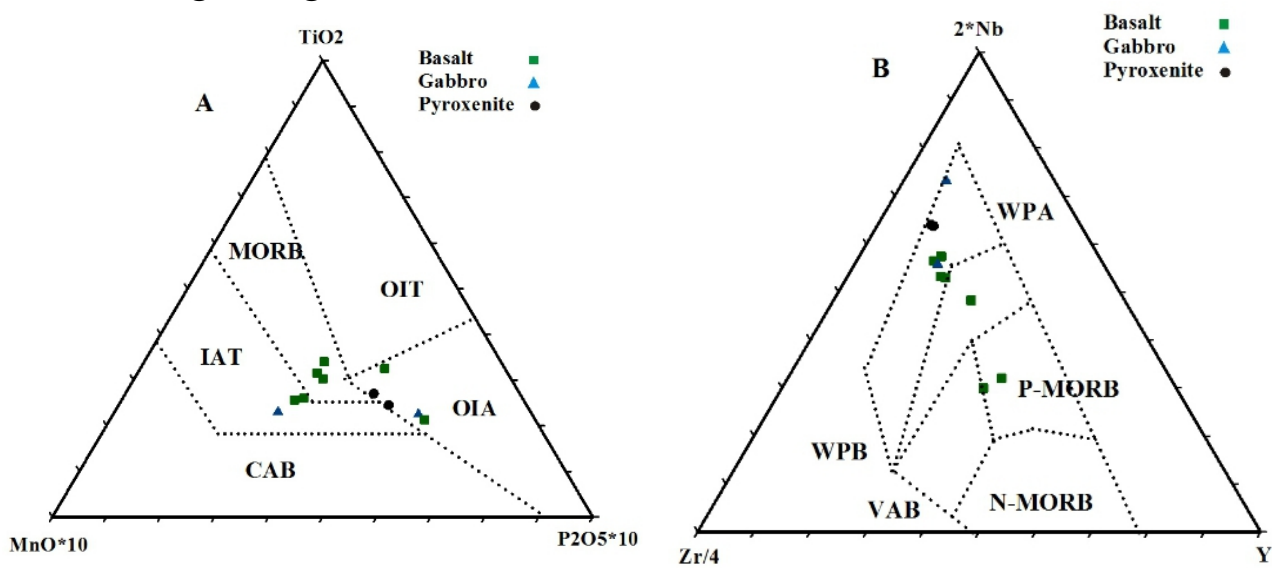

Figure 7: Classification of the mafic and ultramafic rocks of the Akou River in the triangular diagrams. (A) $\mathrm{TiO}_{2}-\mathrm{MnO}-\mathrm{P}_{2} \mathrm{O}_{5}$ from Mullen (1983). Nb-There- $\mathrm{Zr}$ of Meschede

(1986). Caption: black round: Pyroxenite, blue Triangle: Gabbro, green Square: basalt.

CAB: calc-alkali basalt. OIA: ocean island alkali basalt. OIT: ocean island tholeiite. MORB: mid-ocean ridge basalt. IAT: island arc tholeiite. N-MORB: normal mid-ocean ridge basalt. N-MORB: plume mid-ocean ridge basalt. WPA: within plate alkali basalt. WPT: within plate tholeiitic basalt. VAB : volcanic-arc basalt.

The spectra of the incompatible elements of the mafic and ultramafic rocks of the Akou river standardized with primitive mantle (Sun et McDonough 1989) show overall an enrichment $\mathrm{Rb}$, $\mathrm{Ba}$ (LILE: large ion lithophile elements) and $\mathrm{Nb}$ (HFSE: high field strengh elements) and a impoverishment $\mathrm{Zr}$ and $\mathrm{Y}$. These spectra present also an enrichment and a fractionation out of light rare earths (LREE, Le and Ce) with respect to heavy rare earths (HREE, Y) characterized by the slope of the right-hand side. The absence of a $\mathrm{Nb}$ anomaly, the enrichment of the incompatible elements and the fractionation of the LREE ( $\mathrm{Le}$ and $\mathrm{Ce}$ ) by report/ratio HREE (Y) are arguments which justify the character anorogenic (alkaline) magmas and their origins starting from a mantellic source (Wilson, 1989). 


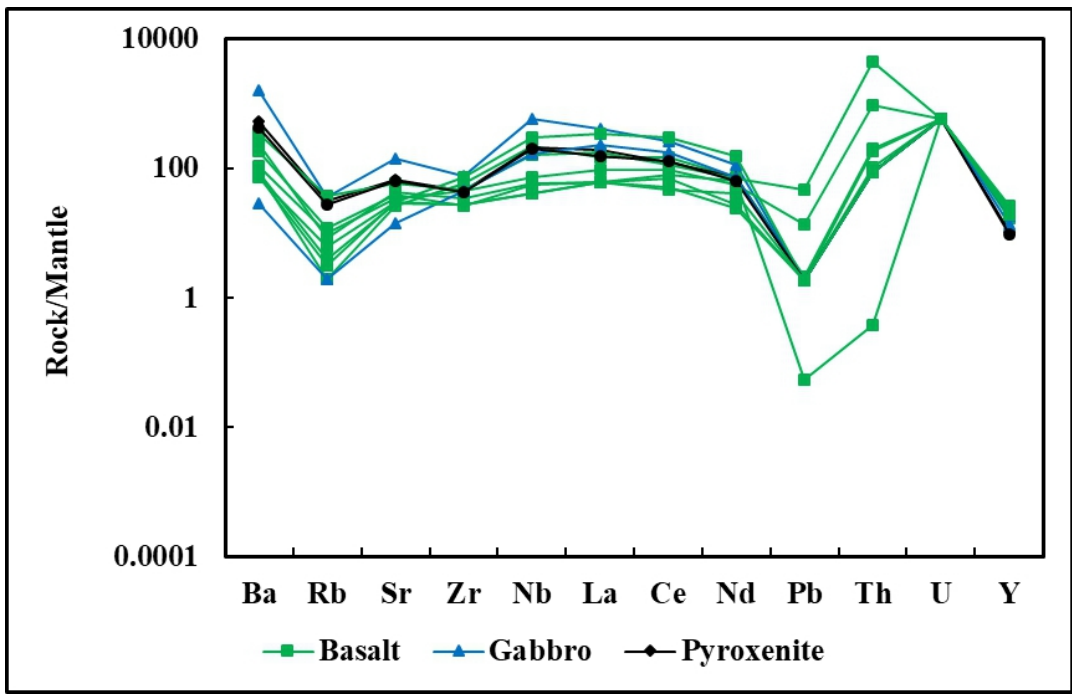

Figure 8: Spectra of standardization of the incompatible elements of the mafic and ultramafic rocks of the Akou River. Standardization was made by report/ratio primitive mantle (Sun et McDonough, 1989).

\section{Discussion and conclusion}

The Okondja basin experienced significant magmatic activity marked by the presence of massive igneous blocks. In the area of Ambinda, these magmatic rocks are varied (basalts, gabbros and pyroxenites) and from several origins. Their low values of ignition loss (less than $2 \%$ ) indicate unaltered rocks. Akou river basalts are mafic rocks, from an within plate rifting volcanism (Weber et al., 2003). These rocks are dominantly alkaline with two samples found in the sub-alkaline field rocks (tholeitic). This is in agreement with the anorogenic series regroup the alkaline and tholeiitic series. This anorogenic context is associated with the Okondja basin. Gabbro and pyroxenite are plutonic rocks related to the crystallization of an alkali magma. The petrographic composition of gabbro and pyroxenite samples (olivine, pyroxene amphibole and biotite) shows a degree of similarity. Chemically, also, these rocks are similar. The history of the mafic and ultramafic rocks of the Akou River can be summarized as follows:

The first stage corresponds to the intrusion of the basaltic sill into the upper cold crust. The second stage corresponds to the crystallization (fractional crystallization) of the sill, the crystals decate and successively form the pyroxenites and the gabbros.

This model of the mafic and ultramafic rocks of the Akou River is justified by the presence of cumulative facies, pyroxenites and gabbros, although the ideal sequence (dunite, gabbro and granodiorite) has not been observed. Pyroxenites and gabbros have well developed millimeter-sized minerals, characteristic of a cumulative texture. These rocks are composed of 
olivine and pyroxenes for pyroxenites and amphiboles for gabbros. The basalts described are typical of lavas. These rocks appear to be linked to a series of alkaline magmas from a rifting area. These magmas; from a mantelic origin; are related with the rifting processes. Our results are in agreement with Lhachmi et al., 2001 who showed that the Central High Atlas of Morocco consists of alkaline magmatic rocks. The petrographic and geochemical characteristics are in agreement with a magmatic differentiation, by fractional crystallization. So, Ait Chayeb et al., 1998, described the magmatism of Argana, Western High Atlas (Morocco) as a magmatism in relation to the intracontinental rifting that preceded the Opening of the Central Atlantic. This anorogenic magmatism marks a stage of rifting of little extension at the origin of the abortion of the rift. Al Gouti et al., 2001 consider the series of the Adoudounian base as an alkaline magmatism of intracontinental distant tectonics, related to rifting affecting the West African craton. Peridotites are generally associated with gabbros and volcanic rocks. The volcanogenic rocks of the Akou River are paleoproterozoic rocks. These rocks are associated with mantellic rocks (pyroxenites and gabbros). This organization is similar with the sediments, which cover the mantellic rocks constituting the Hutuo unit, in the Trans-North-China-Belt (North China Craton) (Traps, 2007; Zhao et al., 2005). Pyroxenites and gabbros would be the equivalent of the archaean rocks of the North China Craton (NCC).

The mafic and ultramafic rocks of Akou River are the alkaline rocks resulting by process of split cristallization. The succession of sedimentary deposits above mantellic rocks characterize an oceanic crust. The rocks are associated with within plate oceanic volcanicity.

\section{References:}

1. Ait Chayeb, E.H., Youbi N.,El Boukhari A., Bouabdelli M.,Amrhar M. (1998). Le volcanisme permien et mesozoique infériur du bassin d'Argana (Haut-Atlas occidental, Maroc): un magmatisme intraplaque associé à l'ouverture de l'Atlantique central. Journal of African Earth Sciences, vol. 26, No. 4 pp 499-519.

2. Albani, A.E.L., Bengtson, S., Canfield, D.E., Bekker, A., Macchiarelli, R., Mazurier, A., Hammarlund, E.U., Boulvais, P., Dupuy, J.-J., Fontaine, C., Fursich, F.T., Gauthier-Lafaye, F., Janvier, P., Javaux, E., Ossa, F.O., Pierson-Wickmann, A.-C., Riboulleau, A., Sardini, P., Vachard, D., Whitehouse, M. and Meunier, A. (2010) Large Colonial Organisms with Coordinated Growth in Oxygenated Environments 2.1 Gyr Ago. Nature, 466, 100-104.

3. Algouti, Ab., Algouti, Ah., Chbani, B., Zaim, M. 2001. Sédimentologie et volcanisme synsédimentaire de la série de base de l'adounien infracambrien à travers deux exemples de l'Anti-Atlas du Maroc. Journal 
of African Earth Science, vol. 32, No.4 pp 541-556.

4. Azzibrouck-Azziley, G. (1986). Sédimentologie et géochimie du Francevillien B (Protérozoïque Inférieur). Métallogénie des gisements de manganèse de Moanda (Gabon). Thèse de doctorat de l'Université Louis Pasteur, Strasbourg, 214p.

5. Edou-Minko, A., Moussavou, M., Sato, T. , Sawaki, Y., Ndong Ondo, S. , Maire, R. , Fleury, G. , Mbina Mounguengui, M. , Kaestner, A. , Ortega, R. , Roudeau, S. , Carmona, A. , Makaya Mvoubou., Musavu Moussavou, B. , Sasaki, O. and Maruyama, S. (2017) Growth, Duplication and Lateral Mutual Compressive Deformation of Akouemma hemisphaeria on the Seafloor of Okondja Basin at $2.2 \mathrm{Ga}$ (Gabon). International Journal of Geosciences, 8, 1172-1191. Doi: 10.4236/89067.

6. Edou-Minko, A., Moussavou, M., Sato, T., Tchikoundzi, C., Sawaki, Y., Ndong Ondo, S., Ortega, R., Maire, R., Kaestner, A., Mbina Mounguengui, M., Roudeau, S., Fleury, G., Carmona, A., de Parseval, P.H., Mvoubou, M., Musavu Moussavou, B., Ogandaga Agondjo, M., Sasaki, O. and Maruyama, S. (2016). An Akouemma hemisphaeria Organic Macrofossils Colony Hosting Biodiversity Assemblage on the Seafloor of Okondja Basin (Gabon) Dated at $2.2 \mathrm{Ga}$, Journal of Geology \& Geophysics, 6, 281.

7. Feybesse, J.L, Johan, V., Triboulet, C., Guerrot, C., Mayaga-Mikolo, F., Bouchot, V., Eko N'dong, j. (1998). The west central african belt: A model of 2.5-2.0 Ga accretion and two phase orogenic evolution. Precambrian research 87, 161-216.

8. Gauthier-Lafaye, F. (1986). Les gisements d'uranium du Gabon et les réacteurs d'Oklo. Modèle métallogénique de gîtes à fortes teneurs du Protérozoïque inférieur. Thèse Universtité Louis Pasteurs de Strasbourg, 206p.

9. Guillon, J-H. (1969). Données nouvelles sur la composition et la structure du grand massif péridotique du sud de la nouvelle calédonie, Cah. ORSTOM, sér. Géol., I, 1, 7-25.

10. Haubensack, C. (1981). Environnement des grès protérozoiques et des indices uranifères du secteur Kiéné dans le bassin de Franceville au abon. Aspect sédimentologiques et géochimiques. Thèse. de doctorat de l'université Louis Pasteur, 101p.

11. Irvin, T.N. and Baragar, W.R.A. (1971). A guid to the chemical classification of the common volcanic rocks. Canadian journal earth sciences 8, 523-288.

12. Le Bas, M.J., Le Maitre, R.W., Streckeisen, A. and Zanettin, B. (1986). Achemical classification of volcanique rocks based on the total alkalisilica diagram. Journal petrology 27, 745-750. 
13. Le Maitre, R.W., Bateman, P., Dudek, A., Keller, J., Lameyre, M.J., Le Bas, P.A., Sabine, R., Schmid, H., Sørenson, J., Streckeisen, A., Woolley, A.R., Zanettin, B. (1989). A Classification of Igneous Rocks and Glossary of Terms. Blackwell, Oxford, 193p.

14. Lhachmi, A. (2001). Petrogenesis of the Anemzi Mesozoic alkaline intrusion, Central High Atlas, Morocco. Journal of African Earth Sciences, vol.32, No.4, pp741-764.

15. Mayaga-Mikolo, F. (1996). Chronologie des événements sédimentaires, magmatiques et tectonométamorphiques du Précambrien d'Afrique Centrale et Occidentale (Gabon): Tectonogenèse Ogooué et héritage archéen. Thèse de 1'Université Blaise Pascal, Clermont Ferrand.

16. Meschede, M. (1986). A method of discrimnation between different types of mid-ocean ridge basalts and continental tholeites with the $\mathrm{Nb}$ Zr-Y diagram. Chemical geology 56, 207-218.

17. Moussavou, M., Edou-Minko, A., Mbina Mounguengui, M., Ortega, R., Fleury, G., Roudeau, S., Carmona, A., Genty, D., Blamart, D., Tchikoundzi, C., Makaya, M., Musavu Moussavou, B., Ndong Ondo, S., Ogandaga Agondjo, M., Dewilde, F., Delorme, G., de Parseval, P., Weil, R. and Maire, R. (2015). Multicellular Consortia Preserved in Biogenic Ductile-Plastic Specimens of Okondja Basin (Gabon) by 2.1 Ga. Journal Geology Geosciences, 4, 195.

18. Mullen, M. (1983). MnO-P2O5-TiO2: a major element discriminant for basaltic rock of environments, and its implications for petrogenesis. Earth planetary. Sciences letters 62, 53-62.

19. Ossa-Ossa, F.G. (2010). Etude multi-approches du bassin sédimentaire paléoprotérozoïque (2.1-2.4 Ga) de Franceville au Gabon : les environnements sédimentaires et l'impact des paléocirculations de fluides. Thèse université de Poitiers, $191 \mathrm{p}$.

20. Pambo, F. (2004). Sédimentologie, géochimie et minéralogie d'une formation manganésifère paléoprotérozoïque et des minerais associés. Exemple du gisement de Moanda au Sud-Est du Gabon. Thèse de de doctorat de l'université de Bourgogne, $274 \mathrm{p}$.

21. Parrot, J.-P. (1969). Etude d'une coupe de référence dans le cortège ophiolitique du pinde septentrional (Grèce): la vallée de l'Aspropotamos, Cah. 0RSTOM, shr. G\&O, I, 2,35-59.

22. Sawaki, Y., Moussavou, M., Sato, T., Suzuki, K., Ligna, C., Asanuma, H., Sakata, S., Obayashi, H., Hirata, T., Edou-Minko, A. (2016). Chronological constraints on the Paleoproterozoic Francevillian Group in Gabon, Geoscience Frontiers, doi: 10.1016/2016.10.001.

23. Sun, S.S. and McDonough, W.F., (1989). Chemical and isotopic systematics of oceanic baslats : implication for mantle composition 
and process. In Magmatism in the Ocean Basins (Edited by Saunders, A.D. and Norry, M.) Journal Geological Society London 42, 313-345.

24. Trap., P, (2007). Style tectonique et contexte géodynamique au Paléoprotérozoïque .Exemple du Craton de Chine du Nord. Tectonique. Université d'Orléans. Français.

25. Weber, F. (1968). Une série précambrienne du Gabon: le Francevillien, sédimentologie, géochimie, relations avec les gîtes minéraux. Mémoire du Service de Cartographie Géologique d'Alsace Lorraine, $328 \mathrm{p}$.

26. Weber, F. (1969). Une série précambrienne du Gabon: Le Francevillien sédimentologie, géochimie, relations avec les gites minéraux associés. Thèse d'état de doctorat de l'Université Louis Pasteur, Strasbourg, 328 p.

27. Weber, F., Gauthier-Lafaye, F. (2013). No proof from carbon isotopes in the Francevillian (Gabon) and Onega (Fennoscandian shield) basins of a global oxidation event at 1980-2090 Ma following the Great Oxidation Event (GOE)-Comptes Rendus Geoscience, 345, 28-35.

28. Weber, F., Gauthier-Lafaye, F., Whitechurch, H., Ulrich, M, El Albani, A. (2016). The 2-Ga Eburnean Orogeny in Gabon and the opening of the Francevillian intracratonic basins: A review, Comptes Rendus Geoscience, Volume 348, 572-586.

29. Wilson, M. (1989). Igneous petrogenesis. A global tectonic approach. Unwin hyman Ltd, Londres.

30. Winchester, J. and Floyd, P. (1976). Magma type and tectonic setting discrimination using immobile elements. Earth planetary sciences letters 27, 211-218.

31. Zhao, G.C., Sun, M., Wilde, S.A., Li, S., (2005). Late Archean to Paleoproterozoic evolution of the North China Craton: key issues revisited. Precambrian Research 136, 177-202. 